\title{
Meningkatkan Hasil Belajar Siswa Pada Mata Pelajaran Fisika Dengan Model Pembelajaran Problem Solving Pada Siswa Kelas XII IPA SMA Negeri 1 Buntulia Tahun Pelajaran 2019/2020
}

\author{
Mei Saleh \\ Guru SMA Negeri 1 Buntulia \\ meisaleh@gmail.com
}

Received: 13 August 2021; Revised: 02 October 2021; Accepted: 14 December 2021

DOI: http://dx.doi.org/10.37905/aksara.8.1.369-374.2022

\begin{abstract}
Abstrak
Penelitian ini adalah penelitian tindakan kelas yang bertujuan untuk meningkatkan jumlah siswa yang mencapai kriteria ketuntasan belajar fisika melalui penerapan pembelajaran berbasis masalah tipe Problem Solving pada siswa Kelas XII IPA SMA Negeri 1 Buntulia. Subjek penelitian ini adalah siswa Kelas XII IPA SMA Negeri 1 Buntulia tahun pelajaran 2019/2020 dengan jumlah 24 orang. Pengumpulan data dilakukan dengan teknik tes dan observasi. Hasil analisis data memperlihatkan bahwa: (1) pada siklus I, skor rata-rata hasil belajar siswa mencapai 62,12 dari skor ideal 100, dan persentase siswa yang mencapai kriteria ketuntasan minimal sebesar $66,67 \%$ (2) pada siklus II, skor rata-rata hasil belajar siswa mencapai 79,74 dari nilai ideal 100 dan persentase siswa yang mencapai kriteria ketuntasan minimal sebesar 91,30\%. (3) keaktifan siswa dalam proses pembelajaran juga mengalami peningkatan dari siklus I ke siklus II.
\end{abstract}

Kata Kunci: Hasil belajar, problem solving

\section{PENDAHULUAN}

Minat belajar merupakan bentuk ketertarikan, keinginan siswa untuk melakukan hal, tugas, latihan, yang berkaitan dengan pembelajaran. Dengan meningkatnya minat siswa dalam belajar maka secara signifikan prestasi hasil belajarpun secara otomatis akan baik. Dengan demikian peranan minat menjadi sangat penting/dominan berkaitan dengan upaya peningkatan hasil belajar siswa.

Kenyataan yang terjadi dalam pembelajaran sering dijumpai hal-hal yang tidak mendukung dalam rangka pencapaian hasil belajar seperti minat atau keinginan siswa dalam belajar yang relatif masih rendah, beberapa kompetensi dasar sebagai tujuan pembelajaran yang belum mampu tercapai sesuai dengan standar kriteria ketuntasan minimal (KKM) yang diharapkan dan sebagainya, sehingga perlu dilakukan upaya atau langkah konkret untuk meningkatkan minat atau motivasi belajar pada siswa. Minat belajar merupakan bentuk ketertarikan, keinginan siswa untuk melakukan hal , tugas , latihan, yang berkaitan dengan pembelajaran. Dengan meningkatnya minat siswa dalam belajar maka secara signifikan prestasi hasil belajarpun secara otomatis akan baik. Dengan demikian peranan minat menjadi sangat penting/dominan berkaitan dengan upaya peningkatan hasil belajar siswa.

Oleh karena itu, idealnya dalam belajar fisika fakta, konsep dan prinsip-prinsip tidak boleh diterima begitu saja oleh siswa tanpa melalui pemahaman dan penalaran karena tidak akan mengembangkan kemampuan berpikirnya. Tetapi kenyataannya, dalam proses pembelajaran di kelas lebih banyak diarahkan kepada kemampuan untuk menghafal informasi. Akibatnya siswa akan kaya dengan teori tetapi sangat miskin dalam aplikasi. 
Berdasarkan observasi dan informasi yang diperoleh tentang proses pembelajaran yang dilaksanakan selama ini di sekolah tersebut mengungkapkan bahwa pembelajaran fisika yang dilakukan di sekolah itu masih berorientasi pada pola pembelajaran yang lebih banyak didominasi oleh guru. Pengembangan potensi siswa khususnya kreativitas berpikir selama pembelajaran belum optimal, sehingga berakibat pada perolehan hasil belajar siswa yang tidak optimal pula. Kategori ketuntasan belajar untuk mata pelajaran Fisika di sekolah tersebut adalah 60, meskipun demikian masih banyak siswa memperoleh nilai di bawah standar ketuntasan tersebut. Biasanya hanya sekitar 30\% dari jumlah siswa yang memenuhi standar tersebut.

Untuk meningkatkan jumlah siswa yang memenuhi standar ketuntasan tersebut, diperlukan suatu upaya nyata salah satu diantaranya adalah memperbaiki proses pembelajaran yang terjadi di kelas melalui penggunaan model pembelajaran yang berbeda dari sebelumnya. Penggunaan model pembelajaran itu diharapkan dapat membuat siswa menggunakan konsep fisika dan mengingatnya lebih lama.

Penggunaan model pembelajaran yang sesuai dengan karakteristik materi yang diajarkannya akan membuat guru dapat berkomunikasi baik dengan siswanya, membuka wawasan berpikir yang beragam dari seluruh siswa, sehingga siswa dapat mempelajari seluruh konsep dengan baik Jika hal itu tercapai, maka siswa tidak lagi bosan belajar fisika, bahkan siswa yang tadinya membenci pelajaran ini menjadi bersemangat dan mulai menyukai fisika sedikit demi sedikit.

Salah satu model pembelajaran yang dapat membuat siswa menjadi lebih aktif dan kreatif, dalam menyelesaikan soal-soal fisika, menumbuhkan motivasi dan minat siswa dalam belajar, adalah model pembelajaran berbasis masalah. Tipe Problem Solving. Penggunaan model pembelajaran ini diharapkan dapat menjawab permasalahan berikut ini; Apakah jumlah siswa yang memenuhi standar ketuntasan belajar minimal dalam mata pelajaran fisika dapat ditingkatkan melalui penggunaan model pembelajaran berbasis masalah. Tipe Problem Solving.

\section{METODE PENELITIAN}

Jenis penelitian ini adalah penelitian tindakan kelas dengan tahapan-tahapan pelaksanaan yang meliputi: perencanaan, pelaksanaan tindakan, pengamatan atau observasi, analisis, dan refleksi. Subjek penelitian adalah siswa Kelas XII IPA SMA Negeri 1 Buntulia.

Penelitian tindakan kelas ini dilaksanakan dalam dua siklus, tiap siklus memiliki tahapan sebagai berikut: 1) tahap perencanaan, 2) tahap pelak-sanaan tindakan, 3) tahap pengamatan dan pengumpulan data, 4) tahap refleksi. Siklus I dan II berlangsung sebanyak empat kali pertemuan (8 jam pelajaran).

Teknik pengumpulan data yang dilakukan dalam penelitian ini adalah sebagai berikut: Data hasil belajar siswa dikumpulkan melalui tes hasil belajar dalam bentuk essay tes, data aktivitas siswa dan aktifitas guru dikumpulkan melalui observasi. Data yang terkumpul dianalisis dengan menggunakan analisis statistik deskriptif dan kualitatif. Indikator keberhasilan dari penelitian ini adalah minimal 85 persen siswa mencapai skor tes hasil belajar minimal 60. 


\section{PEMBAHASAN}

Adapun analisis persentase skor perolehan hasil belajar fisika siswa setelah penerapan model pembelajaran berbasis masalah tipe Creative Problem Solving (CPS) dapat dilihat pada tabel berikut:

Tabel 1. Perbandingan hasil belajar tiap siklus

\begin{tabular}{|l|l|l|l|}
\hline \multirow{2}{*}{ Siklus } & \multicolumn{3}{|l|}{ Skor Perolehan Siswa } \\
\cline { 2 - 4 } & Skor tertinggi & Skor terendah & Rata-rata \\
\hline 1 & 88,00 & 40,00 & 62,12 \\
\hline 2 & 100,00 & 48,00 & 79,74 \\
\hline
\end{tabular}

Tabel 2 Perbandingan ketuntasan belajar fisika siswa tiap siklus

\begin{tabular}{|l|l|l|l|l|}
\hline \multirow{2}{*}{ Siklus } & \multicolumn{2}{|l|}{ Frekuensi } & \multicolumn{2}{|l|}{ Persentase (\%) } \\
\cline { 2 - 5 } & Tuntas & $\begin{array}{l}\text { Tidak } \\
\text { tuntas }\end{array}$ & Tuntas & Tidak tuntas \\
\hline 1 & 16 & 8 & 66,67 & 33,33 \\
\hline 2 & 21 & 2 & 91,30 & 8,70 \\
\hline
\end{tabular}

Dari tabel 1, tampak bahwa dari 24 orang Siswa SMA Negeri 1 Buntulia yang menjadi subjek penelitian dapat diuraikan sebagai berikut :

a. 66,67 \% siswa Kelas XII IPA SMA Negeri 1 Buntulia dikategorikan tuntas pada siklus 1 dan meningkat menjadi 91,30\% pada siklus 2 .

b. 33,33\% siswa kelas XII IPA SMA Negeri 1 Buntulia dikategorikan tidak tuntas dan menurun menjadi $8,70 \%$ pada siklus 2 .

Hasil ini menunjukkan bahwa ketuntasan belajar fisika siswa kelas XII IPA SMA Negeri 1 Buntulia dalam mempelajari materi IPA Fisika melalui penerapan pembelajaran berbasis masalah tipe problem solving pada siklus 2 telah mencapai target indikator keberhasilan dalam penelitian yaitu $91,30 \%$ yang memiliki nilai di atas KKM dari $85 \%$ yang ditargetkan. Hal ini menunjukkan bahwa pembelajaran fisika dengan menggunakan pembelajaran berbasis masalah tipe problem solving pada siklus 2 berhasil meningkatkan hasil belajar fisika siswa Kelas XII IPA SMA Negeri 1 Buntulia

Dari perbandingan hasil observasi pada siklus I dan siklus II jika dilihat dari persentase perolehan maka dapat dikatakan bahwa terjadi peningkatan aktivitas siswa. Keberhasilan tersebut antara lain disebabkan oleh. Usaha yang dilakukan oleh peneliti adalah untuk membuat LKS siswa lebih menarik dibandingkan dengan LKS yang biasa ia gunakan dan penggunaan media power point untuk mendukung praktikum pada siklus II. Hal ini membuat siswa kreatif dan berusaha mencari sendiri jawaban dari permasalahan yang dimunculkan, sehingga siswa dapat lebih memahami materi fisika karena mereka yang menemukannya sendiri (bermakna).

Dari hasil evaluasi kegiatan di siklus 1 menunjukkan bahwa ketuntasan belajar fisika siswa Kelas XII IPA SMA Negeri 1 Buntulia belum mencapai target yang diharapkan, yakni baru 66,67 \% yang memperoleh nilai 60 ke atas dari 85\% yang ditargetkan.

Hasil analisis data observasi merekomendasikan beberapa hal yang perlu diperbaiki pada siklus kedua yaitu: 
1. Kesiapan siswa saat orientasi masalah,

2. Keberanian siswa untuk menjawab pertanyaan.

3. Kemampuan siswa bekerja sama mengerjakan LKS nya.

Upaya untuk memperbaiki hal tersebut di siklus II dilakukan dengan cara sebagai berikut: Pada saat orientasi masalah guru tidak berdiri di depan kelas (di depan kelompok 1 dan 2), tetapi di tengah kelas untuk mengontrol seluruh kelompok. Untuk membangkitkan keberanian siswa untuk menjawab pertanyaan-pertanyaan dan bekerjasama dalam kelompok, Guru memberikan motivasi dan arahan kepada kelompok yang terdeteksi kurang berani dan kurang kerjasama di siklus 1.

Berdasarkan hasil analisis data yang telah dilakukan pada bagian sebelumnya,maka secara deskriptif penelitian ini dapat menunjukkan perbedaan hasil belajar yang diperoleh siswa pada siklus I dan siklus II hal ini berarti bahwa penerapan pembelajaran berbasis masalah tipe problem solving dapat meningkatkan hasil belajar siswa. Keberhasilan ini tercapai antara lain karena dalam pembelajaran berbasis masalah tipe problem solving, siswa diberi kesempatan untuk mengalami sendiri, berkreasi menyelesaikan masalah dengan cara mereka sendiri. Hal ini sejalan dengan yang diungkapkan Pepkin (2004), yaitu ketika siswa dihadapkan pada permasalahan, siswa diberi kesempatan untuk memilih dan mengembangkan tanggapannya, sehingga siswa tidak hanya menghafal tanpa pikir.

Pembelajaran berbasis masalah tipe problem solving memiliki keunggulan sebagai berikut:

1. Siswa dilibatkan pada kegiatan belajar sehingga pengetahuan dapat diserapnya dengan baik.

2. Dilatih untuk dapat bekerja sama dengan siswa lain.

3. Siswa memiliki keterampilan dan cara berpikir sesuai konsep IPA.

Hal ini dapat dilihat dari keaktifan siswa dalam mengikuti pembelajaran, yaitu pada saat mereka diorientasikan pada masalah, baik pada siklus I maupun pada siklus II. Mereka pada umumnya mulai mandiri untuk mencari tahu masalah yang dikemukakan oleh guru.

Selain keuggulannya, pembelajaran berbasis masalah tipe problem solving memiliki kelemahan, yaitu, membutuhkan banyak waktu tatap muka. Membutuhkan persiapan yang matang oleh seorang guru. Untuk mengatasi hal ini, guru terlebih dahulu menyiapkan segala perangkat pembelajaran, termasuk LKS serta kebutuhan praktikum.

\section{KESIMPULAN}

Berdasarkan hasil analisis data dan pembahasan yang telah diuraikan sebelumnya bab sebelumnya, maka dapat disimpulkan bahwa penggunaan Model pembelajaran berbasis masalah tipe Problem Solving dalam pembelajaran Fisika di kelas XII IPA SMA Negeri 1 Buntulia Kabupaten Pohuwato dapat meningkatkan jumlah siswa yang memenuhi standar ketuntasan belajar minimum (KKM).

Untuk meningkatkan hasil belajar fisika dengan menerapkan pembelajaran berbasis masalah tipe Problem Solving direkomendasikan untuk menempuh langkahlangkah sebagai berikut : a) dalam mengorganisasikan siswa untuk belajar, sebaiknya guru membagi siswa ke dalam kelompok kecil, 4-5 orang (adanya kerja sama antara siswa dapat memperbanyak peluang siswa untuk saling berdialog dalam mengembangkan keterampilan sosial dan keterampilan berpikir). dan b) untuk 
memaksimalkan keaktifan siswa dalam belajar dan mengembangkan keterampilan sosial dan keterampilan berpikir, LKS yang dibuat oleh guru sebaiknya hanya mencantumkan alat dan bahan yang dibutuhkan. Guru memberikan kesempatan kepada siswa untuk melaksanakan praktikum dengan prosedur kerja mereka sendiri.

\section{DAFTAR PUSTAKA}

Arikunto, Suharsimi. 2005. Dasar-Dasar Evaluasi Pendidikan. Jakarta: Bumi Aksara.

Anonim, 2009, Model Pembelajaran Creative Problem Solving dengan Video Compact Disk dalam Pembelajaran Matematika, http://rmakoe.wordpress.com, 29 januari 2009, diakses 06 Mei 2009.

Bahri Djamarah, Syaiful \& Zain, Aswar. 2006. Strategi Belajar Mengajar. Jakarta: Asdi Mahasatya.

Hamalik, Oemar. 2004. Proses Belajar Mengajar. Jakarta: Bumi Aksara.

Hamzah B. Uno, Haji. 2007. Model Pembelajaran. Jakarta: Bumi Aksara.

Ibrahim, Muslimin. 2000. Pembelajaran Berdasarkan Masalah. Surabaya: Universitas Negeri Surabaya.

Kunandar. 2008. Langkah Mudah Penelitian Tindakan Kelas sebagai Pengembangan Profesi Guru. Jakarta: RajaGrafindo Pratama.

Lutfizulfi, 2008, Model-model Pembelajaran Inovatif untuk Digunakan Guru, http://www.infogue.com, 06 Agustus 2009.

Natsir, Muhammad. 2004. Stategi Pembelajaran Fisika. Makassar: Laboratorium Jurusan Fisika Universitas Negeri Makassar.

Sanjaya, Wina. 2007. Strategi Pembelajaran Berorientasi Standar Proses Pendidikan. Jakarta: Kencana Prenada Media Group.

Trianto. 2007. Model-Model Pembelajaran Inovatif Berorientasi Konstruktivistik. Jakarta: Prestasi Pustaka. 
AKSARA: Jurnal Ilmu Pendidikan Nonformal

P-ISSN 2407-8018 E-ISSN 2721-7310 DOI prefix 10.37905

Volume 08, (1), January 2022

http://ejurnal.pps.ung.ac.id/index.php/Aksara 